\title{
CHAPTER THIRTEEN
}

\section{TRANSLATION STUDIES - VONDEL'S APPROPRIATION OF GROTIUS'S SOPHOMPANEAS (1635)}

\author{
Madeleine Kasten
}

\section{Life, Text and Interpretation}

On 15 July 1634, Hugo Grotius presents his esteemed and loyal friend Gerard Vossius with a play by his hand entitled Sophompaneas. As he explains in his dedicatory letter, the piece has three points to commend it. First of all, it is a tragedy and thus belongs to the 'royal' genre that was not disdained by prominent men such as Sophocles, or the emperor Augustus. Secondly, although the plot conforms to the Aristotelian ideal it is drawn not from the misfortunes of Troy or Thebes - matter that has been tainted by the story-telling Greeks! - but from biblical history, which is free from falsehood. Finally, the play offers a portrait of an exemplary ruler, and in this respect it complements the examples of the first three Patriarchs, on whose lives, according to Philo Judaeus, Moses the lawgiver intended us to model our own. ${ }^{1}$

The exemplary regent in question is Joseph, son of Jacob and Rachel, whose history we find recorded in Genesis 37-50. More specifically, Grotius's play centres on the episode in which Joseph, having been exalted to the position of governor of Egypt, confronts and forgives his brothers, who had sold him into slavery in his youth. As a humanist, Grotius presents his protagonist in the light of those qualities that mark him out as a universal example, and the play may thus be classified as a

\footnotetext{
${ }^{1}$ Grotius, Sophompaneas, pp. 126-33. Unless stated otherwise, all references to Grotius's play, including the translations, are from the edition by Arthur Eyffinger. Daniel Heinsius, a Dutch humanist and former friend of Grotius, had singled out the popular theme of Joseph in Egypt as the only one in the Bible to answer Aristotle's preference for a complex plot where the moment of recognition (agnitio) coincides with a reversal of fortune or peripeteia (Eyffinger, Sophompaneas, pp. 3-4). In his dedicatory letter, Grotius forestalls any possible criticism concerning the exitus felix of his tragedy by mentioning a number of classical tragedies that likewise lack a sad ending, including Euripides' Iphigeneia in Tauris, a play he had recently translated into Latin himself.
} 
mirror for magistrates. However, various readers and critics have pointed out that the author must have been aware of certain striking similarities between Joseph's story and his own vicissitudes. ${ }^{2}$

A brilliant and internationally acclaimed jurist, theologian, classicist, and historian, Grotius had been intended for a career in politics. After a promising start, however, he got caught up in the politicoreligious controversies of his day and was sentenced to life imprisonment in the Dutch castle of Loevestein (1618), from which, helped by his wife, he managed to escape in a book chest three years later. His subsequent years were spent in exile, first in Paris and later, after a failed attempt to return to Holland, near Hamburg. Moved by feelings of bitter resentment towards his home country he had long been looking around for new prospects. At last, in 1634, an opening presented itself as the Swedish chancellor Axel Oxenstierna offered him the post of ambassador to the Swedish crown in Paris.

This appointment, as Grotius may have perceived it, would enable him to further European-Christian unity and promote his ideas for a universal system of natural law set forth in his treatise De iure belli ac pacis (On the Law of War and Peace, 1625). It would thus afford him an opportunity to prove his statesmanship, in circumstances which may well have put him in mind of Joseph's foreign career. Like Joseph, Grotius had been forced into exile; like his protagonist, he may have sensed the hand of God in the reversal of fortune that was once more to call him to public office. His conciliatory letters to the States of Holland and the Dutch stadtholder, Frederick Henry, suggest his intention to follow Joseph's example in repaying evil with good, ${ }^{3}$ while the play itself contains several possible allusions to the parallel, notably Grotius's confusion, in the original draft, between his own term of exile and that of Joseph. ${ }^{4}$

One early reader on whom this parallel was certainly not lost was Vondel, who, like Grotius's son Pieter, produced a Dutch translation of the play in the year of its first appearance. The personal relationship between Vondel and Grotius dates back to 1631, when Vondel came to visit his countryman in the latter's temporary hiding place in

${ }^{2}$ Eyffinger, Sophompaneas, pp. 67-72.

${ }_{3}^{3}$ Eyffinger, Sophompaneas, p. 66.

4 Sophompaneas, pp. 999-1000. This slip, among other possible clues, was first noted by Van Vollenhoven, whose interpretation of the play's genesis I am following here (Verspreide Geschriften I, pp. 238-39). 
Amsterdam. In 1628, Vondel had already dedicated his Dutch translation of Seneca's Hippolytus to Grotius. In 1637, two years after his work on Sophompaneas, he honoured Grotius again with the dedication of his play Gysbreght van Aemstel. Vondel's much later Adam in ballingschap (Adam Exiled, 1664) is an adaptation of Grotius's Adamus exul (Adam Exiled, 1601), and as late as 1668 he was to render Grotius's Latin translation of Euripides' Phoenician Women in Dutch.

In the preface to his Sofompaneas Vondel reflects that as he was engaged in the delightful task of translation, he 'sometimes imagined that either Joseph had been resurrected in the poet, or the poet had followed in Joseph's footsteps' ('[Ick] hier mede vast in 't vertolcken en rijmen bezigh en verruckt zijnde, liet my zomtijds voorstaen, dat Iosef, of in den treurspeelder verrezen was, of dat de treurspeelder Iosefs spoor moest bewandelt hebben'). ${ }^{5}$ This comment, disarming in its show of admiration for Grotius, may nevertheless be seen to serve a double purpose. First of all, its chiastic structure (Joseph-poet/poet-Joseph) suggests a relationship of reciprocity to the point of interchangeability between the Genesis account and Grotius's poetic adaptation. Yet where could such a relationship exist except in the perception of a reader/translator sufficiently skilled to register the similarity and eager, for his part, to cap this tour de force by achieving an analogous relationship to his original and its biblical pretext? Vondel's subsequent statement that he has tried neither to follow too closely on the heels of Grotius's Latin nor to stray from his illustrious predecessor too far does little to mask this aspiration, despite his modest assurance that whether he and his two helpers have struck the right balance in this respect is for the Great Intellect himself to decide. ${ }^{6}$

Vondel's desire to revive the image of the Patriarch through Grotius is characteristic of an age and culture which saw translatio as a first step towards the time-honoured ideal of imitatio et aemulatio. Yet we may ask to what extent he succeeded in his endeavour, even if Grotius declared himself thoroughly satisfied with the job. ${ }^{7}$ It is this question that I will try to answer here, although I should make it clear from the

${ }^{5}$ Sofompaneas, p. 435. Unless stated otherwise, all translations from Vondel are my own. To distinguish between Vondel's translation and Grotius's original I will refer to Vondel's work by means of its Dutch title, Sofompaneas.

${ }^{6}$ Sofompaneas, p. 435. Vondel's fond epithet for Grotius, 'the Great Intellect' (Dutch 'het Groote Vernuft'), is a pun on his Dutch name, De Groot. Vondel's two helpers were the playwright Daniël Mostert and the lawyer Joan Victorijn.

7 Eyffinger, Sophompaneas, p. 88. 
start that the issues I want to highlight do not begin or end with Vondel's translation. They are far more pervasive and cannot be properly separated from more general problems of imitation and interpretation. Significantly, the Latin noun interpretatio encompasses both the translator's and the interpreter's activities, and the latitude for ideological appropriation created by these overlapping meanings compromises the notion of 'translation proper' from its very beginnings. ${ }^{8}$ In the case of Sofompaneas, the difficulty is moreover compounded by the circumstance that Vondel's Neo-Latin source text was itself both a linguistic and generic adaptation and a radical cultural appropriation of the Hebrew Bible story. In Grotius's play, Vondel encountered a version of the Genesis story that had already been mediated by the perspective of a contemporary who was, moreover, a western intellectual and a Christian.

Grotius's play and Vondel's translation represent only two among numerous early modern adaptations of the popular Joseph theme. To determine Vondel's position within this larger intertextual framework it is not enough merely to judge his labour in terms of its faithfulness to Grotius's original. Although the scope of this paper does not allow me to follow up all of the intertextual leads, I will make a start by referring Vondel's and Grotius's achievements to their common biblical source. After all, even though Vondel's own stated intention on this occasion was to produce a 'translation proper' we will see that the dominant paradigm of translation in his time would have allowed him scope for considerable alterations with regard to his original. Before embarking on my analysis, however, it will be necessary - however briefly - to outline this paradigm, and to mark some historical shifts in the western approach to translation.

\section{Invisibility in Translation}

Although translation studies as an academic discipline established itself only in the second half of the twentieth century, the reflection on translation as a practice goes back to antiquity. Frederick Rener, in his

\footnotetext{
${ }^{8}$ Roman Jakobson, in his essay 'On Linguistic Aspects of Translation', distinguishes between three types of translation: intralingual translation or 'rewording', intersemiotic translation or 'transmutation', and interlingual translation or 'translation proper' (p. 114).
} 
history of translation from Cicero to Tytler, argues that changing views with regard to literary translation over the centuries are directly attributable to changes in perception concerning the relationship between language and the world. Until the end of the eighteenth century, he explains, this relationship was largely defined in terms of the classical distinction between res and verba. Whereas words might be seen to differ from one language to another, their referents were regarded as universal and unchangeable. This outlook, in its turn, presupposed a relationship of full, unproblematic equivalence between the individual languages.

Following Cicero, translators generally took a liberal view of their art. Interestingly, they often compared their labour to a change of costume. ${ }^{9}$ Vondel, in the preface to his translation of the French poet $\mathrm{Du}$ Bartas' La Magnificence de Salomon, resorts to this very topos to justify his enterprise:

But even though fear at times made me shrink [from the task of translation], a secret passion would compel me to see how I might adorn and embellish this French Venus with a Dutch apparel and costume $[. . .]^{10}$

Where the preservation of meaning - the body underneath the changed apparel - was taken to be a priori guaranteed, the translator's ideal would be to produce a fluent text which strove to conceal its derived nature at any cost.

Partly through the influence of Descartes and Locke, the eighteenth century sees a change in this respect. By this time, the insight is growing that our perception of reality is to a large extent shaped by language, and the old distinction between res and verba comes under fire. Friedrich Schleiermacher, in his essay 'Über die verschiedenen Methoden des Übersetzens' ('On the Different Methods of Translating', 1813), advocates a new approach to the translation of scholarly and literary texts. Unlike his predecessors he rejects the idea that a translation could or, indeed, should copy the meaning of its original. After all, every text is produced within a specific cultural and historical context, and this context is rooted primarily in language. Even apart from being impossible an exact translation would be undesirable since, in Schleiermacher's view, the purpose of a translation should be to expose

\footnotetext{
${ }^{9}$ Rener, Interpretatio, pp. 24-26.

10 'Maer gelijck my vreeze zomtijds dede deynzen, alzoo noopte my wederom een heymelijcke hertstocht om eenmael te zien hoe ick deze fransche Venus met een neerlands gewaed en hulsel zoude mogen toijen en opsmucken [...]', Heerlyckheyd, p. 229.
} 
its reader to a foreign language and culture. Accordingly, he declares himself in favour of a more 'alienating' mode of translation designed to preserve the characteristics of the source text as far as possible. The resulting target text, he asserts, should not gloss over the traces of the translator's pains to achieve this goal.

With regard to the theory of translation it is safe to say that Schleiermacher's relativistic approach has withstood the test of time. Particularly the advent of (post)structuralism, with its insistence on the arbitrary and unstable nature of the linguistic sign, has done much to reinforce the insight that a translation can never be more than an interpretation of its original. ${ }^{11}$ By contrast, Schleiermacher's call for an alienating practice of translation has met with little response.

Lawrence Venuti, in The Translator's Invisibility, examines the consequences of what he deems to be a constant of the art of translation through the centuries. Although Venuti's survey is primarily concerned with dominant practices of translation in the Anglo-Saxon world its relevance is not restricted to this context. In order for a text to gain approval, he argues, it has always been essential that it should read fluently - an effect which the translator achieves by adapting his style and usage to the audience of his target text. As a result, however, the translated text is likely to give the impression of being an original rather than a translation. By erasing the traces of his own interference, the translator disguises the secondary status of his work. The typical result is an illusion of presence: presence of the 'voice' of the original, to which the reader has direct access. To put it in Venuti's words, ' $\mathrm{t}$ ] he more fluent the translation, the more invisible the translator, and, presumably, the more visible the writer or meaning of the foreign text. ${ }^{12}$

This brings us back to Vondel's assertion that while he was translating, he sometimes imagined that he was either encountering Grotius in Joseph, or vice versa. On the one hand his desire to lend presence to not one, but both of these sources seems wildly ambitious even in terms of the ubiquitous tendency signalled by Venuti. On the other hand, it is important to note that Vondel produced his translation at a time long before interpretatio, in its double sense of translation and interpretation, came to be conceived as a problem at all. In the closing sentence

${ }^{11}$ An interesting survey of new approaches is Difference in Translation, a collection of essays edited by Joseph Graham. See especially Graham's introduction, pp. 13-30.

${ }_{12}$ Venuti, The Translator's Invisibility, p. 2. 
of his preface, where he refers the judgement of his work to Grotius himself, he significantly invites the Great Intellect to 'rebuke our Dutch Sofompaneas in his stammering, and to render him in Dutch as perfectly as in Latin.' ${ }^{13}$ This open invitation to the author to emulate his translator is telling in several respects. Firstly, it confirms the idea, prevalent in Vondel's time, that perfection in translation is an attainable goal: the true master can render his text in one language as well as in another. Secondly, it reduces the question of perfection to one of 'mere' words, of masterly eloquence as opposed to the beginner's stammer. Finally, and perhaps most fundamentally, it obscures the difference between 'translation proper' - if such a thing should indeed exist - and the prior act of interpretatio by which Grotius had translated 'his' Joseph from the Book of Genesis to his own Neo-Latin play, drawing inspiration from a great many other sources in the process. ${ }^{14}$

This blurring of the different senses of interpretatio is entirely of a piece with the fact that translation, in Vondel's era, was regarded as an integral part of a learning programme whose goal was to train the student in the imitation of the classical masters. ${ }^{15}$ Vondel himself, in his Aenleidinge ter Nederduitsche dichtkunste (Introduction to Dutch Poetry), claims that

Knowledge of foreign languages is a great advantage, and translating the illustrious Poets will help the aspiring Poet in the same way that the Painter's apprentice may benefit from copying great masterpieces. [...] Thus one copies the art from the best masters, learning, through artful theft, to leave to others what is theirs. ${ }^{16}$

13 'Maer of wy hier in de rechte maete houden, dat zal het Groote Vernuft [...] kunnen oordeelen, wanneer het zich gewaerdige onzen Neerlandschen Sofompaneas in zijn stamelen te berispen, en hem zoo volmaeckt in het Duitsch als in Latijn te leveren [...].' (Sofompaneas, p. 435)

${ }^{14}$ I quote Grotius's own account: 'The history of this tragedy is recorded by Moses in Genesis, chapters 44 and 45 and the adjoining context. It is furthermore to be found in Psalm 125, in chapter 7 of the Acts of the Apostles, in Philo's Life of Joseph, in the second book of the Antiquities by Josephus, the father of Jewish historiography, and parts of it also in Justinus' excerpt from book 26 of Pompeius Trogus. It is also recorded in Artapanus, who drew on Alexander Polyhistor, and in Demetrius; the relevant references are listed in Eusebius' Preparation of the Gospel' (Sophompaneas, p. 147). In addition to these listed sources, Grotius's play contains countless allusions to, and stylistic resonances with, the classical masters.

${ }^{15}$ See Jansen, Imitatio, esp. ch. 4, pp. 144-53.

16 'Kennis van uitheemsche spraecken vordert niet weinigh, en het overzetten uit vermaerde Poëten helpt den aenkomende Poeet, gelijck het kopieeren van kunstige meesterstucken den Schildersleerling. [...] Zoo ziet men den besten meesteren de 
The term 'theft' suggests that there is more involved here than a simple drill. Indeed Venuti, in his study, makes it clear that precisely where the art of translation appears most effortless, the translated text reveals its thieving designs upon its original. For its illusory transparence does not come to it naturally: it is the result of appropriation and suppression of the cultural other. The audience within the receiving culture finds its standards and values confirmed in the translation, which thus helps to deflect any 'foreign' influence that might endanger those values.

In the foregoing I have tried to outline the cultural framework within which Vondel operated, linking my observations at the same time to a more general problem of translation. Within this broader context, it remains to be determined why he chose to undertake this particular project, and to assess the result. As a first step towards my analysis I now turn to Grotius's Sophompaneas, a play whose very title presents a vexing problem of translation.

\section{Grotius's Sophompaneas: An Outline}

The title of the play refers to the Egyptian name given to Joseph by Pharaoh in Genesis 41:45, Zaphnath-paaneah. This name, which presents an etymological riddle, has been variously translated as 'the man who discloses secrets', 'a man unto whom secrets are revealed', 'a man and Interpreter of secrets', 'a discoverer of secrets', or, as in Jerome's Vulgate, 'Saviour of the world. ${ }^{17}$ I will return to Jerome's translation at a later stage in my argument.

The beginning of the first act finds Joseph alone while pondering his duties as governor of Egypt. Like Socrates' model ruler in the allegory of the cave, Joseph, too, avows to spurn the trappings of his office: 'I maintain the image, but get no pleasure from it' (utor hoc ego, non fruor, 1. 28). He contrasts his carefree youth in Canaan with his present,

\footnotetext{
kunst af, en leert, behendig stelende, een' ander het zijne te laten.' (Vondel, Aenleidinge ter Nederduytsche dichtkunste, pp. 487-88).

${ }^{17}$ Jerome omits the name Zaphnath-paaneah altogether. He merely states that Pharaoh changed Joseph's name, calling him in the Egyptian tongue the saviour of the world ('vertitque nomen illius et vocavit eum lingua aegyptiaca Salvatorem mundi'). Eyffinger notes that Grotius himself appears to have preferred the Hebrew rendering, 'the man who discloses secrets' (Sophompaneas, p. 148). This reading corresponds to Joseph's self-stated intention in the first act of uncovering the secrets of his brothers' hearts, which are usually veiled in mists (ll. 97-98).
} 
precarious state as a stranger in a high position, calling attention to the seven years of crop failure which are devastating Egypt and giving praise to nature's almighty Father, who has made him, Joseph, the instrument of the country's salvation.

God has made the dreams he sent Joseph as a child come true: from far and near strangers come flocking to Egypt for the grain stored there through the governor's foresight during the previous years of abundance. Even his own brothers have now undertaken the journey for the second time, without, however, having recognized him. Joseph declares himself a mild man who is willing to forgive his kin for their past crimes against him. Yet he feels he must put these brothers - who are actually his half-brothers - to the test, since he fears that the same hatred which drove them to sell him into slavery long ago might cause them to harm young Benjamin, his only full brother and the favourite of their father Jacob in his old age. To this end Joseph has devised a plot by which he hopes either to find them good men, or to make them so. He counsels his son, Manasseh, to follow his own example in repaying evil with good lest he might lose God's favour.

At the opening of the second act Benjamin is taken to Joseph's palace in fetters: his luggage has been found to contain a sacrificial bowl which belongs to Joseph, and which was actually planted there at the latter's command. Judah, one of the brothers, tries to put in a good word for him but is told by Joseph's steward, Ramses, that the supplicants had better examine their own conscience. God's vengeance may be slow, but it is sure, and the adversity which has befallen Benjamin might well be a punishment for a wrong committed by his kin long ago. This admonition does not fail to strike home. At that point, however, the governor himself makes his entrance. He expresses his feigned surprise at the 'crime': how could the brothers have hoped to get away with theft? Were they unaware, then, of his prophetic gift? Judah pleads Benjamin's case once more. He implores Joseph to temper justice with mercy for the sake of old Jacob, who will surely not survive the loss of a second child. Joseph pretends he needs more time to consider the matter.

In Act Three a messenger informs Joseph of a rebellion in Egypt's easternmost province. The trouble has been caused by the greed of the local authorities, who have made good profit by selling the grain intended for the hungry people to buyers abroad. Joseph's interrogation of this messenger allows him to expose the evils of bad government and at the same time to demonstrate his own statesmanship. 
He issues orders to restore the peace without unnecessary bloodshed and henceforth to entrust power to the reliable middle class: ' $T$ T he backbone of society is the middle class - less prone to luxury and free from sordid baseness.' ${ }^{18}$

This scene is overheard by Joseph's brothers Judah and Simeon. The latter, who has spent a year at Joseph's court as a hostage, extols the virtues and political insight of the governor. He shows Judah a picture gallery - a gift to Joseph from Pharaoh - which surrounds the palace courtyard on three sides. Each tablet depicts a scene from Joseph's career in Egypt, starting with the attempt made on his virtue by the wife of Potiphar, his first master. Looking over Judah's shoulder we next follow the protagonist into the dungeon where this woman's false accusations have landed him, but where he also rises to fame thanks to his powers as a dream interpreter. Called upon by Pharaoh himself in this capacity, he confidently predicts a seven-year spell of abundant harvests followed by an equal period of failing crops. He is then elevated to his present dignity and seen to reform the country's government, dividing society into three estates and promoting the arts and sciences. Joseph's crowning achievement, however, has been his counsel to Pharaoh to store up as much grain as possible during the seven years of plenty. By selling these reserves to the people in the subsequent years of famine Pharaoh has become owner not only of all the land, but likewise of the Egyptians themselves and their live stock. Thus he has been able to evict his own people from their dwellings, commanding them to go and expand the empire by colonizing foreign lands.

Interestingly, Simeon now discloses that there is a fourth side to the gallery where Joseph has depicted what the future holds in store for the Egyptians. However, he declines to show Judah these last pictures, explaining that they are unlikely to be of interest to him.

The fourth act centres on Benjamin's trial before Joseph. The governor, on being reminded that Jacob already lost a son long ago, soon elicits Judah's confession that he would give his life to see father and child reunited. Satisfied with this answer, Joseph now proceeds to reveal his own identity by degrees. First he demonstrates his knowledge of the Hebrew tongue by giving the etymology of Benjamin's name, leaving it to Judah to unveil the meaning of his own name,

18 Quod civitatem continet medium est genus, luxu remotem, sorde contemta vacans (ll. 649-50); Sophompaneas, p. 205. This wisdom actually stems from Aristotle's Politics (IV.11). 
Joseph: 'the increase of a happy family' (incrementa felicis domus, 1. 951). Indeed, a joyful reunion ensues in which Joseph fully forgives his brothers for their past misdeeds. Accordingly, he orders them to go and fetch Jacob in order that the whole family may come to live in Egypt, sharing Joseph's power and privileges.

In Act Five, Pharaoh himself arrives at Joseph's palace to offer his congratulations on this happy ending. Joseph seizes the opportunity to secure a promise that his family will be given fertile pastures in Egypt for their cattle. In addition, he asks that they be allowed freedom of religion as well as permission to leave Egypt if they should ever wish to do so. Pharaoh swears a solemn oath that these wishes shall be granted. Joseph concludes the play with a prophecy concerning Egypt's future ties with Israel and the coming of Christ, who will join the two peoples' religions one day.

Each of the five acts is followed by a chorus of Ethiopian women, the maid servants of Joseph's wife Aseneth. The main function of this chorus is to sing Joseph's praises and to highlight particular episodes in his life so as to justify the special favours bestowed on him by God. In Act One, the women begin by setting off the governor's marital fidelity against the sexual excesses of 'barbarian' rulers. ${ }^{19}$ They continue their eulogy by contrasting Joseph's chastity in youth to the lasciviousness of Potiphar's wife. The keyword here is constancy. Unlike 'barbarian' monarchs, Joseph has never allowed himself to be swayed by passion, a claim that is indeed supported throughout the play by his prudent handling of the confrontation with his brothers.

On its second appearance, the chorus raises the broader theme of man's innate capacity for evil. This proneness to sin, in its turn, leads the women to celebrate Joseph's strict and just leadership, which is next demonstrated in Act Three as the governor unfolds his strategy for quenching the rebellion.

God works in mysterious ways which defy human understanding. This mystery is exemplified by Joseph's history, but also, in a more negative sense, by the Nile's present lack of water, a disaster which the

19 The Latin adjective used here is 'barbaricus' ('barbaricae more potentiae', 1. 157), strictly meaning 'non-Greek', 'non-Roman', or simply 'foreign'. Significantly, the Ethiopian servants in Grotius's play identify with the 'foreigner' Joseph to the point of denouncing their own origins as 'foreign'; a phenomenon that has been discussed within the context of postcolonial studies by Homi Bhabha ('Of Mimicry and Man'). Eyffinger's translation of 'barbaricus' as 'Oriental' (Sophompaneas, p. 167) misses this point. 
chorus, on its return, explains as a punishment by God designed to recall man to a life of virtue. The chorus rejoices at Joseph's reconciliation with his brothers and ends the play with the wish that the Ethiopians, too, may one day come to share the benefits of divine providence.

\section{Vondel's Sofompaneas}

In the introduction to his translation, Vondel hails Joseph's appearance on the Neo-Latin stage in the following words:

After the passing of so many centuries the Hebrew enters the Latin drama, playing his character in Latin so excellently that antiquity wonders at it and he can stand his ground next to her unabashed; an honour that is not even granted all of the ancients. ${ }^{20}$

Within a single sentence Vondel not only establishes continuity between the biblical story and Grotius's contemporary drama; he also stages an encounter between the biblical protagonist and the personified classical tradition. This last move allows him to compare Grotius's achievement favourably to that of the ancient masters. Indeed the figures of the playwright and his character appear to blend in the image of the eloquent, Latinized Joseph, an impression that is confirmed a few lines further down as Vondel relates how, in Act One, Joseph lays the foundation for his artfully constructed argument by contrasting his past and present states. ${ }^{21}$ Here, the character becomes indistinguishable from the figure of the artifex himself.

Throughout the introduction the translator's tone is one of unqualified admiration for the author of his original. In his discussion of Vondel's Sofompaneas, Smit notes how, at the time of its appearance, Vondel and Grotius had for years been engaged in friendly correspondence. In the early 1630s Vondel had conceived the idea of writing an epic devoted to the life of Constantine the Great, the Roman emperor who, after his own conversion, had made Christianity a state religion in $324 \mathrm{CE}$. The project became bogged down after the untimely deaths of two of Vondel's children, followed by that of his wife Maeyken in 1635,

${ }_{20}$ 'Na verloop van zoo veele eeuwen koomt de Hebreeuw op het Roomsche toonneel, en speelt zijn personagie zoo deftigh in 't Latijn, dat d'aeloudheid zich des verwondert, en hy onbeteutert neffens haer magh stand houden; een eere, die allen ouden zelfs niet gebeuren en magh.' (Sofompaneas, p. 434).

${ }^{21}$ Sofompaneas, p. 433. 
and was never resumed. Yet in its initial stages Vondel had felt greatly inspired by the encouragement of Grotius, with whom he shared a deep nostalgia for those early ages when, as they both saw it, the Christian Church still constituted a relatively harmonious unity. In his letter of condolence to Vondel on Maeyken's death Grotius expressly counselled his friend to seek comfort in his work on Constantine. ${ }^{22}$ Instead, however, Vondel immediately began his translation of Grotius's Sophompaneas.

Why did Vondel give priority to this 'humble' task over his own ambitious enterprise? Grief at his recent loss, which may have prevented him from immersing himself in more original work, presents one possible reason. However, Smit convincingly argues that Vondel may have drawn consolation from Joseph's story as an example of how man's life is guided not by blind fate but by God, who alone is capable of turning every evil to good. In this context Smit points to a passage in the introduction where the translator praises 'God's wondrous Providence, which may use and manipulate the evil perpetrated by blind people irrespective of their own aims for the preservation of entire kingdoms, lands, and peoples' (' [...] Gods wonderbaere voorzienigheid, die de boosheid der blinde menschen buiten hun wit weet te bezigen en te beleiden tot behoudenisse van geheele koningkrijcken, landen en volcken'). ${ }^{23}$ On the other hand Smit speculates that Vondel may have thought of his translation as being fundamentally connected with his own Constantinade project, since he regarded both the emperor and Joseph as emblems of the just ruler. ${ }^{24}$

The question presents itself to what extent and in what ways we find Vondel's admiration for Grotius reflected in his translation. First of all, I propose to look at some technical aspects. An important intervention to which the Dutch combination of syllabic and accentual verse compelled Vondel concerns his prosody. Where Grotius uses a highly complex pattern of alternating metres, predominantly iambic trimeters and anapaestic dimeters, Vondel sticks to his familiar rhyming alexandrine. Compare his opening, for instance, to that of Grotius, who employs iambic trimeters ${ }^{25}$ here:

22 Smit, Van Pascha tot Noah, 1, pp.155-56.

${ }_{23}$ Smit, Van Pascha tot Noah, 1, pp. 167-68; Sofompaneas, pp. 434-35.

${ }^{24}$ Smit, Van Pascha tot Noah, 1, pp. 156-57.

25 Aristotle recommends the iambic trimeter as the metre that most resembles the natural rhythm of spoken ancient Greek (Poetics 1449a 24-26; cf. Davis and Finke, Literary Criticism and Theory, p. 63). 
Iosephus: Rursum fugata nocte formosum caput

Sol promit orbi, qualis e thalamo novus

Surgit maritus veste purpurea nitens. (Grotius, Sophompaneas, 11. 1-3)

Joseph: $\quad \mathrm{Nu}$ alle duisternis voortvlughtigh is geweken,

Zoo komt het zonnelicht al weder uitgestreecken

Met heerelijcken glans, gelijck in 't purpren kleed

Een prachtigh bruidegom uit zijne kamer treed.

Now that all darkness has fled

the sunlight comes shining forth

with royal lustre, just as, in his crimson robe,

a splendid bridegroom steps forward from his chamber.

(Sofompaneas, 1l. 1-4)

Only in his choruses and in one especially emotional passage (ll. 381414), where Judah laments Benjamin's misfortune, does Vondel shift to a shorter, four-foot iambic line:

Judah: O teere spruit van onzen bloede,

$\mathrm{Nu}$ in uw bloem en eerste vreughd,

Hoe ongeluckigh is uw jeughd

En jongkheid, die niet eens bevroede

In welcke rampen datze leit

Gedompelt (Sofompaneas, 11. 381-86).

O tender offshoot of our blood, now in the joy of thy first bloom, how unfortunate is thy youth, which not even suspects

the disasters into which it has been plunged.

Grotius, at this point, shifts from iambic trimeter to anapaestic dimeter, a marching metre that is commonly reserved for chorus entries. The fact that this is the only occasion - apart from the choruses - where Vondel diverges from his standard alexandrine lends Judah's exclamation special dramatic force, suggesting an intentional effect which, because of Grotius's more frequent changes in metre, is less evident in his source text.

Dramatic intensification also occurs in some of the instances where Vondel expands Grotius's terse Latin expressions to make them fit his own more loosely constructed verse lines. To this end he frequently makes use of the hendiadys, the figure which renders a single idea by two substantives. An example is to be found in the last quote given above, where the synonyms 'jeughd' and 'jongkheid' for 'youth' serve to emphasize the idea of Benjamin's innocence. 
A third feature that deserves attention is Vondel's use of generalizing or popularized Dutch terms for Latin cultural references. One such type of generalization occurs in his translation of the scene in Act Two where Judah, eager to allay the suspicion of theft, sums up the gifts which the brothers have brought Joseph from Canaan. Among the items mentioned is a kind of fruit resembling human fingers ('mortalium imitata digitos poma', 1l. 248-49). Vondel, perhaps taking his cue from a reference in Pliny, brings the mysterious fruit down to the proportions of the comparatively common date ('dadels', 1. 323). Elsewhere, Grotius has a messenger report that the starving mob has taken to eating ibises (1. 552), while Vondel renders the unlucky bird in the Dutch by substituting the familiar 'stork' ('oyevaer', 1. 681). ${ }^{26}$

Another category which may be distinguished in this context concerns the names of planets and stars. Grotius, referring to one of Joseph's prophetic dreams in which he sees the sun, the moon, and eleven stars bow down to him (Gen. 37:9), splits up the number of stars into two separate constellations: the four Hyads and the seven Pleiads (1. 86). Vondel, on the other hand, retains the addition four plus seven but omits the classical names: 'vier en zevenstar' ('four and seven stars', 1. 100). On two occasions Grotius mentions Sirius, a star venerated in ancient Egypt because its appearance spelled the annual floodings of the Nile (1l. 176; 871). The first time Vondel translates 'heat' ('hitte,' 1. 222); the second time, 'Hondsgestarnt' ('Dog Star', l. 1031). ${ }^{27}$ Similarly, Grotius's mythological names for the sun, such as 'Titan' (1. 88, here metonymically invoked as the father of Helios) and 'Phoebus' (1. 730) are rendered as 'Zon' (Vondel, 11. 101 and 882 respectively).

As is illustrated by this last example, Vondel tends to replace the names of classical divinities with the natural elements and goods attributed to them. Thus Grotius's 'Ceres' is in numerous instances rendered as 'grain' ('graen'). When the rebels in Act Three are setting fire to the Egyptian town of Coptos, Grotius has Eurus, god of the east wind, fan the flames (1. 589); Vondel, for his part, contents himself with 'wind' (1. 727). Finally, the sea god Nereus (Grotius, 1. 1208) is ousted by Vondel's 'the salty flood' ('de zoute sprinck', l. 1383).

${ }^{26}$ Both the ibis and the stork belong to the order of Ciconiiformes. Another name for the ibis is 'Egyptian stork'.

${ }_{27}$ The star's Latin name, Sirius, derives from Greek 'seirios', meaning 'hot', 'burning through the heat of the sun'. Sirius is the brightest star in the sky and appears in the constellation Canis Majoris; hence its popular name, Dog Star. 
Geographical references are also frequently made less specific or even omitted. Where Grotius has Joseph recall how, in his youthful days when he tended his father's herd, he had a reed-pipe which would sing to Syrian tunes, Vondel omits the geography completely by translating 'to the tunes of the land'. ${ }^{28}$ Similarly, Benjamin's hair, which has the colour of Lybian gold becomes 'shining hair, which dulls [the colour of] gold: ${ }^{29}$ When Simeon names the tasks pertaining to the office of Egypt's priests, Grotius has them literally offer fragrances from the people of Sheba on the altars, ${ }^{30}$ while Vondel simply translates 'wieroockt' (to offer 'wieroock', or frankincense, l. 956).

To be sure, all of these transformations may be explained by the fact that Vondel intended his translation for a Dutch theatrical audience likely to be less versed in the classics than Grotius's reader. Conversely, in classical Latin texts we commonly find the names of the gods substituted for the things associated with them. Nevertheless, Vondel's interventions clearly reflect the cultural mechanism described by Venuti: the obscuring or 'making invisible' of cultural difference.

In order to expose the ideological implications of this mechanism I will discuss one last example of what I would call 'geographical blurring' in Vondel's Sofompaneas. This concerns his rendering of Grotius's 'Chorus Aethiopissarum' as 'Rey der Moorinnen' ('Chorus of Moorish Women'). Latin 'Aethiops' has the double meaning of 'inhabitant of Ethiopia' and 'black African' (through Greek etymology, which yields the literal translation 'sun-darkened face'). By opting for the translation 'Moorinnen', Vondel obliterates the geographical reference, foregrounding the racial connotation in its stead. After all, the term 'Moor', in Dutch as in English, could refer to any person of a dark complexion. ${ }^{31}$ This one-sided translation may well have been prompted by the chorus's stereotypical blackness, which it is made to advertise on its first appearance. ${ }^{32}$ Yet where Grotius gives the women a specific geographic and cultural origin when he makes them declare that they were 'sent

${ }^{28}$ Syrios modos (1. 42); 'na 's lands wijzen' (1. 52).

${ }^{29}$ Lybico concolor auro coma (1l. 315-16); 'glinstrigh hair, dat goud verdooft' (1. 390).

${ }^{30}$ Sabaeos [...] altaribus adolere odores (11. 808-09).

31 An interesting discussion of the Moor's appearance in Vondel's Palamedes and, more generally, in medieval and early modern European culture appears in FransWillem Korsten, Vondel belicht, pp. 129-37; Sovereignty as Inviolability, pp. 119-26.

32 'You will recognise us by our curly hair which runs riverlike, not forced by iron needles but by sunbeams. We have flat noses and wide nostrils and our skin is marked by the heat of the all too closely shining sun. Like thick fences our lips protect the dazzling whiteness of our ivory teeth' (Grotius, Sophompaneas, 11. 147-52, pp. 165-67). 
from remote Nubian nations on the banks of the River Niger by order of our king, who is descended from the noble line of Cush' (1l. 144-46), Vondel, striking a more generalizing note, translates 'Sent by the King of the Moors, born from a noble family' (1l. 166-67), ${ }^{33}$ although he does mention Nubia and the Niger in the same passage.

Summing up the general characteristics of Vondel's translation I would say that he lives up to his aim not to follow too closely on the heels of Grotius's Latin, at least with regard to his prosody and the semantic issues mentioned above. In all other respects, however, Vondel maintains the structure of his original. In a cultural context where the art of translation was intricately bound up with imitatio, such loyalty was not self-evident. To give just one example: Vondel's much later Adam in ballingschap is an adaptation of Grotius's Adamus exul, a play likewise inspired by a theme taken from Genesis. While Vondel contains many verbal echoes of Grotius's text, he does not shrink from changing some of the characters, adding a wedding banquet in honour of Adam and Eve and skipping Grotius's third act entirely. ${ }^{34}$

Smit agrees with the Dutch poet Albert Verwey in finding the diction of Vondel's Sofompaneas unequal to that of his two translations from Seneca, De Amsteldamsche Hecuba and Hippolytus. The verse contains many enjambments that fail to generate any prosodic effect, he notes, and at times it becomes downright trivial. ${ }^{35}$ Smit reads this inequality as an indication that Vondel had no particular wish to excel with his Sofompaneas. When working on the Seneca plays he had first made prose translations, allowing himself time to devise elegant solutions for the difficult poetical problems he encountered. Smit concludes that these latter translations had been intended as exercises in versemaking, whereas Vondel's chief purpose with his Sofompaneas was to make Grotius's work accessible to a non-Latinate Dutch audience as quickly as possible. In this context he draws attention to Vondel's full title, which reads: Hvigh de Groots Iosef of Sofompaneas. Treurspel. Vertaelt door I. v. Vondel (Hugo Grotius's Joseph or Sophompaneas. Tragedy. Translated by J. v. Vondel). In most of his other translations Vondel includes his own name in the main title, as with Vondelens

\footnotetext{
33 'Gezonden van den vorst der Mooren / Uit een doorluchtigh bloed geboren' (ll. 166-67).

${ }^{34}$ Smit, Van Pascha tot Noah, 3, chapter seven.

35 Smit, Van Pascha tot Noah, 1, pp. 169-70.
} 
Hippolytus. Only in the case of Sofompaneas and two Greek tragedies which he put to verse in his old age, working from his own previous prose translations, does he mention the author of the original in the main title, taking credit 'merely' for the translation.

As far as I am concerned, however, there is more to be said about Vondel's absence from the title of his Sofompaneas. Invoking Venuti's argument concerning the invisibility of the translator I would venture that Vondel takes responsibility for his acts of cultural appropriation as a translator precisely in those instances where he does advertise his own name in the titles of his translated work. That he refrains from doing so in the case of Sofompaneas may be explained by the fact that this time he was dealing with the work of an author who was not only his contemporary but a venerated fellow countryman and a Christian, whose religious views were moreover intimately related to his own. The cultural distance that separated Vondel from Seneca's antique world must have seemed much greater to him than that which separated him from Grotius's biblical setting.

I have noted how Vondel repeatedly alludes to the parallel between Grotius and his protagonist Joseph in his introduction. However, his most remarkable gesture in this direction occurs in the play itself. At the end of Grotius's third act, Simeon concludes his tour of the governor's picture gallery with the observation that Joseph, in his prescience, has reserved the fourth wall of the courtyard for the depiction of his prophecies concerning the Egyptians:

[... for there,] in his prescience, he [i.e. Joseph] has depicted what destiny holds in store for the people of Egypt in centuries to come. ${ }^{36}$

Vondel translates:

Simeon: $\quad[\ldots]$ een profecye Van al wat Faroos volck bejeegnen zal, gestelt

Door last van 't Groot Vernuft, dat veele dingen spelt [...].

([...] a prophecy

of all that will befall Pharaoh's people, decreed

by the Great Intelligence which predicts many things $[\ldots])$.

(Vondel, Sofompaneas, 11. 1000-02)

In substituting his own fond epithet for Grotius - 't Groot Vernuft' for 'Joseph' in this passage, Vondel pays his crowning tribute to his

\footnotetext{
36 Simeon: Saeclis cuncta quae populo Phari / venient, futuris fata mens ibi praescia / disposuit. (Grotius, Sophompaneas, vss 848-50).
} 
friend. At the same time this act of identification marks his blind spot for the cultural difference dividing him and Grotius from the ancient Hebrew setting of the play. For Grotius had taken his theme from the Hebrew Bible, a religious pretext that had itself been appropriated by Christianity long ago. By way of an epilogue to my analysis I will devote a few words to the problem of 'translation proper' as exemplified by a revealing passage in the play's closing act.

\section{Afterword: How Zaphnath-paaneah Came to Save the World}

In Genesis 45:17-20 Pharaoh, having heard of Joseph's reunion with his brothers, sends the latter back to Canaan to fetch their father. They are not to worry about their possessions, he reassures them, for 'the good of all of the land of Egypt is yours' (Gen. 45:20, KJV). When the brothers have returned, Joseph appears before Pharaoh with a delegation to request a place to live and pasture grounds for their flocks: 'And Pharaoh spake unto Joseph, saying, Thy father and thy brethren are come unto thee: The land of Egypt is before thee; in the best of the land make thy father and brethren to dwell; in the land of Goshen make them dwell [...]' (Gen. 47:5-6). Somewhat further on we read that 'Israel dwelt in the land of Egypt, in the country of Goshen; and they had possessions therein, and grew, and multiplied exceedingly' (Gen. 47:27).

Grotius, abiding by the Aristotelian unities, condenses this episode by making Pharaoh pay a visit to Joseph in Act Five. The ruler of Egypt shows himself eager to honour his governor, and when Joseph asks him for the land of Goshen he generously consents. However, Joseph has two more stipulations to make: first, that his kinsmen may retain their religion, and second, that they will never be prevented from leaving Egypt should they wish to do so. Pharaoh, who in this play appears as willing to pay homage to the Jewish God as the rest of his household, ${ }^{37}$ immediately proceeds to swear an oath. Should any future king of the Egyptians fail to honour this oath, he vows, then may Egypt be visited by ten horrible disasters varying from insect plagues to pestilence and the death of its children, and may the sea engulf all of its people. ${ }^{38}$ In other words, Pharaoh unwittingly calls down upon his people the

${ }^{37}$ Compare, for instance, Ramses's pious exhortations in Act Two (Grotius, Sophompaneas 1l. 264-65 and 268-85).

${ }^{38}$ Grotius, Sophompaneas, 1l. 1192-1209. 
Ten Plagues as well as the drowning of Egypt's army in the Red Sea events related in the subsequent book of the Hebrew Bible, Exodus $7-14$.

This instance of tragic irony is immediately followed by a speech in which Joseph predicts a number of events recorded in the Hebrew Bible that will likewise affect the Egyptians. As a true diplomat, however, he omits the disasters related in Exodus, although he does add that Egypt's future prosperity will last only as long as it continues to cherish God's chosen people (1l. 1212-13). Grotius has Joseph conclude his prophecy by predicting the advent of Christ and the New Covenant, which will one day unite the Hebrews and Egyptians as well as their respective religions. The three closing verses are given to the chorus of Ethiopians, who concur in expressing their wish that they, too, may be included in this future blessing:

Let us hope that these good things will come to us and may this celestial ardour, which is warmer than he sun's rays, also kindle the hearts of the Ethiopians. ${ }^{39}$

The rhetorical device employed in Pharaoh's oath and Joseph's subsequent prophecy is the so-called vaticinatio post eventum, the prophecy after the fact. This figure enhances the play's denouement in that it completes the tour of the gallery which had been left unfinished in Act Three, linking past, present, and future in a continuum that is indeed from beginning to end orchestrated by 'God's wondrous Providence', as Vondel had observed in his introduction..$^{40}$ By the same stroke, however, the Genesis account is emptied of its historical content and made to serve Grotius's and Vondel's own Christological perspective as well as their shared vision of a unified Christian world. For this appropriating move Grotius could draw on a long tradition of Judaeo-Christian exegesis which, as early as late antiquity, had come to interpret the Hebrew Bible in its entirety as foreshadowing the coming of Christ and the New Covenant. ${ }^{41}$ Significantly, this tradition looked upon Joseph the Patriarch as one of the chief types of Christ; a circumstance which explains why Jerome, in his Vulgate, 'translates' Joseph's Egyptian name as Salvator mundi.

\footnotetext{
${ }^{39}$ Chorus: Ventet et ad nos tam grande bonum / Et coelestis melior Phoebo / Calor Aethiopum corda perurat. (Grotius, Sophompaneas, 11. 1228-30).

${ }^{40}$ See my note $18 \#$.

${ }^{41}$ See Auerbach, 'Figura'.
} 
One fundamental reason why Vondel contented himself with the secondary role of translator in his Sofompaneas must have been that he felt himself to belong to the same continuum of Christian salvation history as Grotius. Despite the differences that I have pointed out above it is this attitude which, above all, is reflected in his translation. If this seems a rather predictable conclusion it is perhaps time to call in one last exegete. The philosopher Jacques Derrida, in his essay 'Des Tours de Babel' ('Towers of Babel'), dismisses 'translation proper' as an unattainable ideal from the start. To this end, he too invokes the Book of Genesis. God's deliberate confusion of speeches at Babel, he argues, triggers an uncontrollable proliferation of meaning which forever closes the door on a return to the divine Logos. Henceforth, any original will require translations to make itself understood. On the other hand, no translation depends on its original for its survival. ${ }^{42}$

With regard to Vondel's Sofompaneas we may note that this last insight, too, is borne out by the play. For whereas Grotius's Latin version enjoyed only one recorded performance during the humanist period, Vondel's translation became one of his greatest successes on stage. Five years after its appearance he composed two more dramas centring on the life of Joseph, Joseph in Dothan and Josef in Egypten. To make his Sofompaneas fit in with these other two he changed its title to 'Jozef in 't Hof (Joseph at Court). ${ }^{43}$ 'Per flexuosas ambages', ${ }^{44}$ then, he ended up by claiming the play for his own.

${ }^{42}$ Derrida, 'Des Tours', p. 184.

43 'Joseph at Court' (Eyffinger, Sophompaneas, p. 118).

${ }^{44}$ Grotius, Sophompaneas, 1. 976, 'in a roundabout way'; compare Vondel, 'door zoo veel ommewegen, 1. 1145. The phrase occurs in Act Four, as Joseph explains the reasons for his devious course to his brothers. 